\title{
Winds and tides in the mid-latitude Southern Hemisphere upper mesosphere recorded with the Falkland Islands SuperDARN radar
}

\author{
R. E. Hibbins ${ }^{1,2}$, M. P. Freeman ${ }^{2}$, S. E. Milan ${ }^{3}$, and J. M. Ruohoniemi ${ }^{4}$ \\ ${ }^{1}$ Department of Physics, Norwegian University of Science and Technology (NTNU), Trondheim, Norway \\ ${ }^{2}$ British Antarctic Survey, Cambridge, UK \\ ${ }^{3}$ Department of Physics and Astronomy, University of Leicester, Leicester, UK \\ ${ }^{4}$ Virginia Tech, VA, USA
}

Received: 27 May 2011 - Revised: 26 October 2011 - Accepted: 27 October 2011 - Published: 4 November 2011

\begin{abstract}
Meteor wind data from the first year of operation of the Falkland Islands SuperDARN radar $\left(52^{\circ} \mathrm{S}, 59^{\circ} \mathrm{W}\right)$ are used to characterize the atmospheric tides and background winds in the upper mesosphere above the South Atlantic. Strong $\left(>40 \mathrm{~m} \mathrm{~s}^{-1}\right)$ semidiurnal tides are observed in the winter time and large amplitude $\left(>60 \mathrm{~m} \mathrm{~s}^{-1}\right)$ bursts of quasi two-day wave activity are seen in January 2011. Data are in good agreement with those presented from the SAAMER meteor radar $\left(54^{\circ} \mathrm{S}, 68^{\circ} \mathrm{W}\right)$. Comparison with SuperDARN meteor wind data from a geographically similar Northern Hemisphere site at Goose Bay $\left(53^{\circ} \mathrm{N} 60^{\circ} \mathrm{W}\right)$ reveal clear interhemispheric differences especially in the semidiurnal and terdiurnal components of the tides. The winter time amplitudes of the tides are much stronger in the Southern Hemisphere than in the north. Background winds are observed to be significantly more polewards and westwards throughout the year than those predicted by the empirical horizontal wind model HWM07.
\end{abstract}

Keywords. Meteorology and atmospheric dynamics (Climatology; Middle atmosphere dynamics; Waves and tides)

\section{Introduction}

The dynamics of the middle atmosphere is dominated by waves with periods ranging from minutes to years and spatial scales of metres to thousands of kilometres, and the complex interaction between these different oscillations drives the large scale winds in the middle atmosphere (e.g. Fritts and Alexander, 2003; Manson et al., 2003; Fritts et al., 2006; Offermann et al., 2009; Hoffmann et al., 2010). Understand-

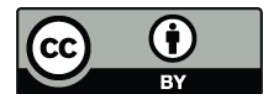

Correspondence to: R. E. Hibbins (robert.hibbins@ntnu.no) ing these interactions, and the associated long-range vertical and horizontal couplings, requires models constrained by long-term satellite or ground-based observational data distributed around the entire globe.

A wealth of ground-based observational data on the dynamics of the middle atmosphere has been recorded from Northern Hemisphere mid-latitude sites in Canada, North America, Europe and Japan (e.g. Luo et al., 2001, 2002; Manson et al., 2004, 2005; Igarashi et al., 2002; Jacobi et al., 2007, 2009; Middleton et al., 2002; Mitchell et al., 1999; Pancheva, 2000; Lysenko et al., 1994; Merzlyakov et al., 2001; Chshyolkova et al., 2005). In contrast, relatively little ground-based data has been reported from equivalent latitudes in the Southern Hemisphere (Brown et al., 1995; Fritts et al., 2010) with the majority of Southern Hemisphere observations coming from lower latitude tropical and extratropical sites (e.g. Pancheva, 2006; Buriti et al., 2008; Andrioli et al., 2009; Guo and Lehmacher, 2009; Lima et al., 2005, 2006; Malinga and Poole, 2002; Kovalam and Vincent, 2003) and high latitude Antarctic stations (e.g. Portnyagin et al., 1998; Baumgaertner et al., 2005; Murphy et al., 2006; Hibbins et al., 2006; Merzlyakov et al., 2009; Sandford et al., 2010)

In this paper we report on the first year of observations from the SuperDARN Falkland Islands radar (FIR) on the dynamics of the upper mesosphere above the South Atlantic. We use meteor trail drift velocities to determine hourly mean horizontal winds around $90 \mathrm{~km}$ altitude and use these to characterize the background winds, the quasi two-day wave and the diurnal, semidiurnal and terdiurnal tidal motions. We compare our results with those derived from the SAAMER meteor radar at Tierra del Fuego (Fritts et al., 2010), higher latitude Southern Hemisphere observations, the horizontal wind model HWM-07 (Drob et al., 2008) and data recorded from a Northern Hemisphere SuperDARN radar of nearly identical latitude and longitude at Goose Bay in Canada.

Published by Copernicus Publications on behalf of the European Geosciences Union. 


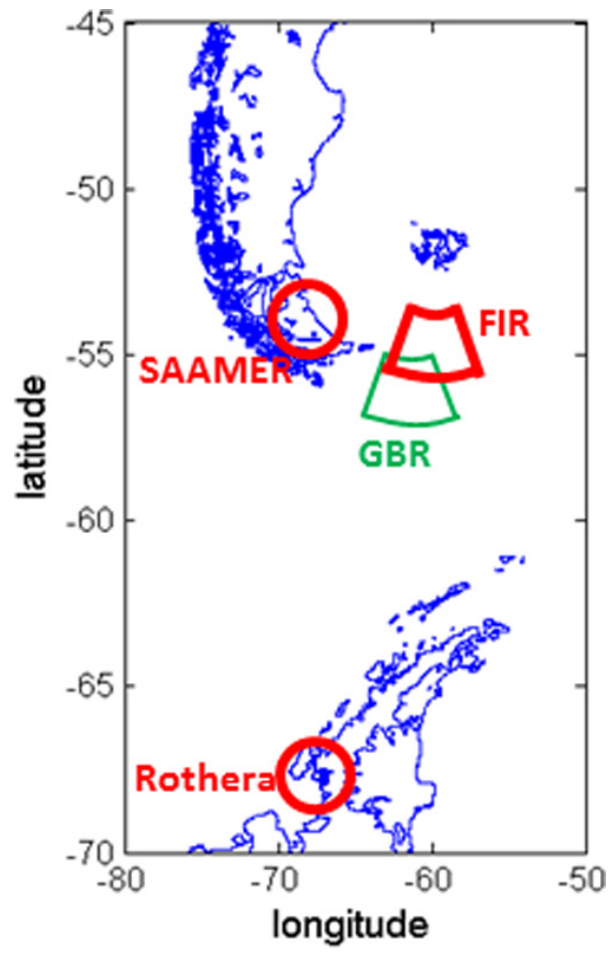

Fig. 1. Map showing the approximate field of view of the Falkland Islands SuperDARN radar (FIR) together with the SAAMER and Rothera radars referred to in the text. The green box labeled GBR represents the equivalent Northern Hemisphere field of view of the Goose Bay SuperDARN radar.

\section{Instrument and data}

The Super Dual Auroral Radar Network (SuperDARN) is an international collaboration that operates networks of HF radars in both the Northern and Southern Hemispheres to support research on Earth's upper atmosphere (Greenwald et al., 1985, 1995; Chisham et al., 2007). The deployment of a SuperDARN radar in the Falkland Islands is a collaborative project between the British Antarctic Survey and the University of Leicester funded by the UK Natural Environment Research Council. The main goals of the project are to:

- study upward-propagating acoustic gravity waves in the thermosphere over the Southern Andes/Antarctic Peninsula gravity wave "hot spot", and ascertain source regions based on the relationship to the lower atmosphere and aurora,

- derive climatologies of the dynamics of the Southern Hemisphere mid-latitude upper mesosphere and investigate the latitudinal extent of non-migrating modes of tidal oscillations in the Southern Hemisphere,

- improve estimates of particle radial diffusion in the outer radiation belt, and provide key data for an empiri- cal model of convective transport in the outer radiation belt.

The radar was deployed during the Austral summer of 20092010 at Goose Green $\left(51^{\circ} 50^{\prime} \mathrm{S}, 58^{\circ} 59^{\prime} \mathrm{W}\right)$ in the Falkland Islands (see Fig. 1). The site is a few metres above sea level and has an unobstructed view towards the south with a boresite $=+178.3^{\circ}$ (i.e. the angle east of geographic north). The radar transmits a multi-pulse sequence at typically about $12 \mathrm{MHz}$ and derives power and line-of-sight velocity data from the 16-lag complex autocorrelation function of the received signal in typically 75 or 110 range gates at $45 \mathrm{~km}$ spacing. The radar array forms a narrow beam that is electronically steered through 16 positions separated by $3.24^{\circ}$ in $1 \mathrm{~min}$. After testing and commissioning, the radar has operated near-continuously since 18 February 2010. Figure 2 summarises the data coverage as a function of date and hour of day from 18 February 2010 to 28 February 2011, which comprises the dataset used throughout this paper. The period around early April 2010 is the only period of downtime longer than 3 days and there is no tendency for the radar to fail around a particular time of day and hence no diurnal bias in the data coverage.

Two-component horizontal winds around $90 \mathrm{~km}$ altitude were calculated from radar echoes from meteor ablation trails using the technique described in Hibbins et al. (2007a). Briefly, a singular value decomposition fit to the individual meteor drift velocities recorded in the first four range gates of the radar between 180 and $405 \mathrm{~km}$ was performed for each hour of operation provided meteors were recorded in at least 5 different beams during the hour (Hall et al., 1997; Bristow et al., 1999; Hussey et al., 2000; Yukimatu and Tsutsumi, 2002).

Figure 3 shows the seasonal and diurnal variation in mean number of meteor echoes recorded per hour throughout the year of operation of the radar. In common with other midlatitude meteor radars, FIR sees a maximum in meteor count rates around local morning (approx. 06:00-08:00 UT, 02:0004:00 LT) and a minimum $12 \mathrm{~h}$ later probably due to the sporadic meteor radiant distribution (e.g. Younger et al., 2009). The monthly mean count rate around the daily maximum is 5-7 times higher than the minimum $12 \mathrm{~h}$ later. During the summer solstice the diurnal count rate peak shifts to later in the day (around 10:00-16:00 UT, 06:00-12:00 LT). As a result of this natural variability, the fitted hourly mean horizontal wind vector typically has a higher standard error during the second half of the day than during the morning. In addition, as a result of the poleward pointing geometry of the radar and the relatively small spread in azimuth of the 16 beams, the meridional component of the fitted wind vector is usually better defined than the zonal component with a typical hourly mean standard error around half that of the zonal component of the horizontal wind vector. 


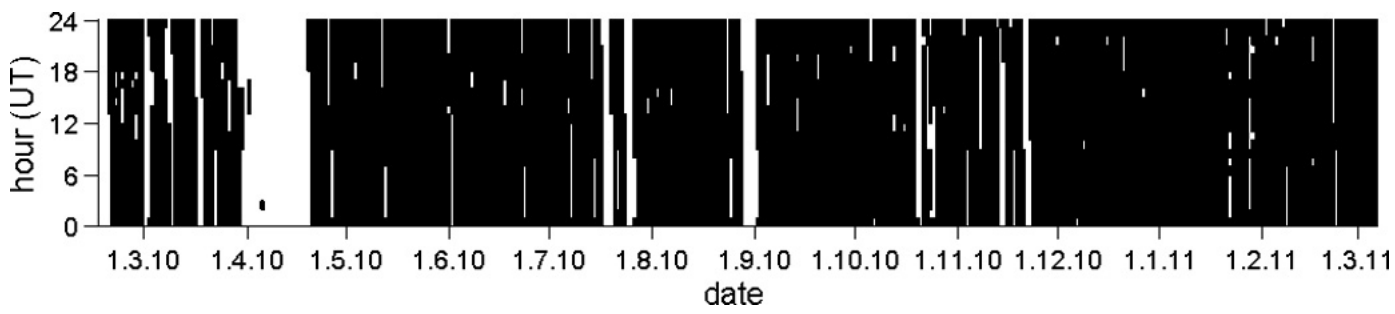

Fig. 2. Times during which the radar data were of sufficient quality to generate a horizontal wind vector. Data are plotted as date and hour of day, missing data are white.

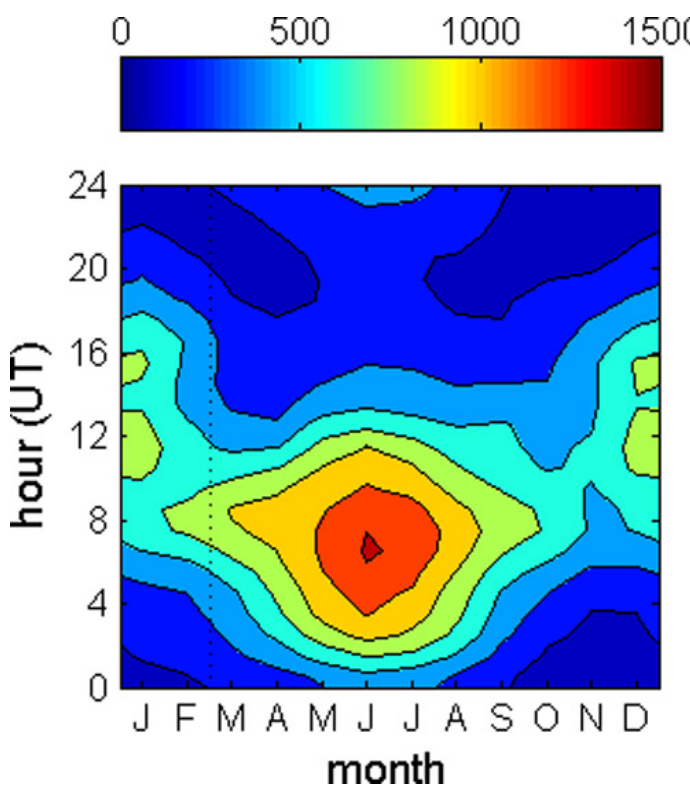

Fig. 3. Hourly mean meteor counts plotted by month and hour of day. The vertical dotted line on this and subsequent annual plots represents the break between data recorded in 2010 and 2011 (see Fig. 2).

\section{Results}

To separate the high frequency periodic oscillations from the background wind, the data were divided into 4-day segments and a non-linear least-squares fit was performed to sine waves with periods of $48,24,12$ and $8 \mathrm{~h}$ provided at least $48 \mathrm{~h}$ of data spanning at least 16 different hours were present in the 4-day period. The data were then stepped by one day and the fitting procedure repeated. The zonal and meridional components were treated independently in the fitting procedure. An example of the raw meridional wind data, the fourcomponent fit and derived parameters is presented in Fig. 4 for the time period covering days 145 to 149 of 2010, during which the semidiurnal tide was particularly strong (amplitude $27.9 \pm 1.3 \mathrm{~m} \mathrm{~s}^{-1}$ ). In this case, the four fitted components together account for $\sim 88 \%$ of the total variance in the four-day hourly mean time series.

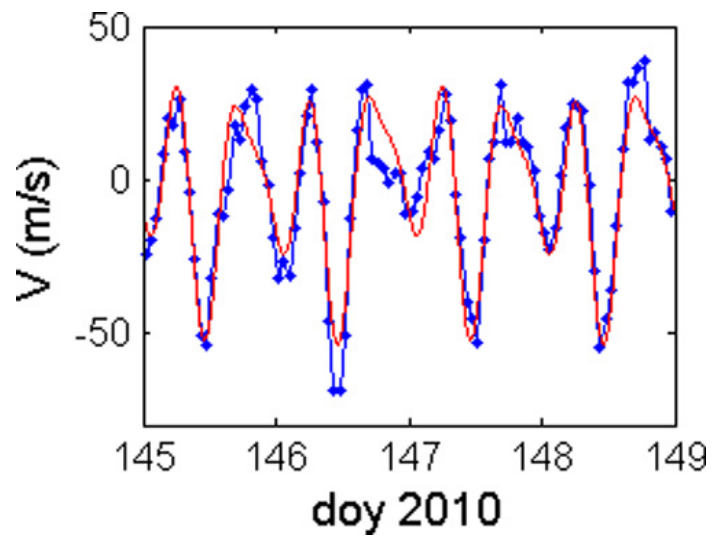

Fig. 4. An example of a four-component non-linear least-squares fit (red) to 4 days of hourly mean meridional wind (blue) during a period of strong semidiurnal tide.

Figure 5 shows the time series of the background wind (Fig. 5e) and the amplitude and phase of the four fitted components (Fig. 5a-d) for the entire 1-year dataset. The daily raw fitted data are presented without smoothing. The 48-h component (Fig. 5a) is small during most of the year with a highly variable fitted phase as expected from a weak component. However, from late December 2010 the amplitude of the component is seen to increase rapidly in three bursts, reaching a maximum amplitude of $\sim 60 \mathrm{~m} \mathrm{~s}^{-1}$ in the meridional component on the 20 January 2011 during the second burst. During this period of strong quasi two day wave activity the phase of the fit is initially seen to decrease by $\sim 1.5 \mathrm{~h}$ per day suggesting that the resultant wave responsible for the oscillation has a period of $46.5 \mathrm{~h}$ (i.e. $1.5 \mathrm{~h}$ shorter than the fitted 48-h component). This behavior is then reversed in early February 2011 when the phase advances by $\sim 3 \mathrm{~h}$ per day indicative of a $\sim 51-\mathrm{h}$ oscillation.

The 24-h fitted component (Fig. 5b), representative of the diurnal tide, is weak throughout the year. The phase is at its most stable around the equinoxes and the early summer, especially in the meridional component of the wave. After late December 2010 the phase is seen to gradually advance over a complete cycle in $\sim 45$ days, but with much day-to-day variability. Conversely, the 12 -h component of the fit (Fig. 5c) is 


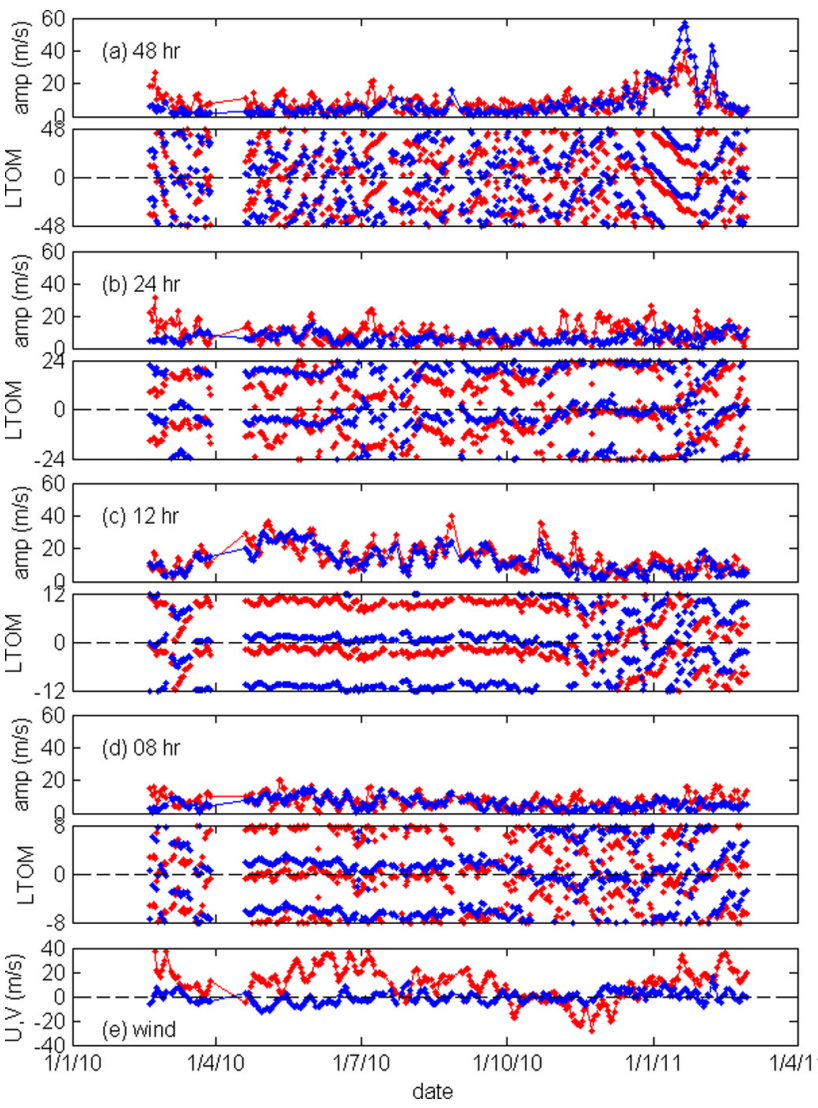

Fig. 5. Amplitude and phase of the daily fitted 48-h (a), 24-h (b), 12-h (c), and 8-h (d) waves, and the background wind (e). The zonal component (positive eastward) is shown in red and the meridional component (positive northward) is shown in blue. Wave phases are plotted as local time of maximum (LTOM) and are repeated over two cycles to show coherence.

strong, and outside of the summer months, has a clearly defined phase with the zonal component leading the meridional by $\sim 3 \mathrm{~h}$. The wave is strongest in May and a secondary maximum is evident in late winter. During the summer months (beginning around early November 2010) the wave weakens and the phase stability with time breaks down such that the phase is no longer locked in local time although the zonal component still tends to lead the meridional. In addition, during winter there is some evidence for a modulation of the amplitude of the wave at a periodicity of around 16 days. This modulation lasts for approximately 150 days from June until October 2010 accounting for around $50 \%$ of the amplitude of the wave. The 8-h fitted component (Fig. 5d) displays similar properties to the 12-h wave although at a much smaller amplitude. The amplitude maximizes in early winter during which the phase is stable with respect to local time, but during summer the wave is weaker with a varying fitted phase.

In general the background zonal wind is largely eastwards apart from a period between October and December 2010,
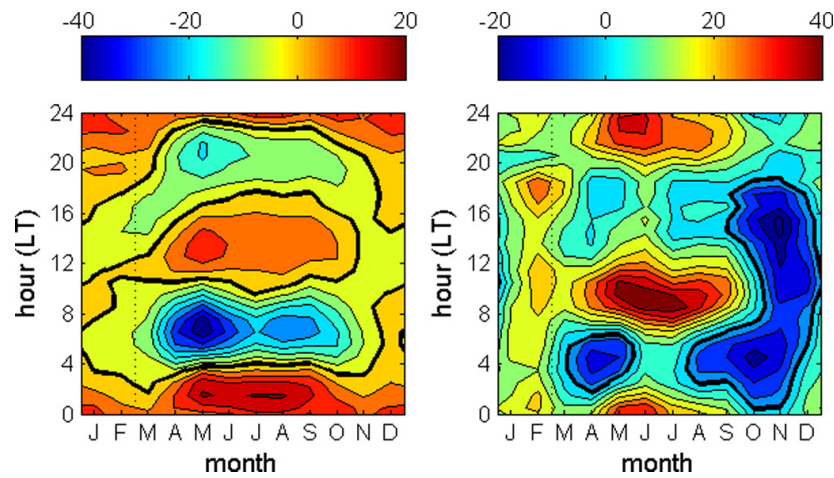

Fig. 6. Hourly mean meridional (left panel) and zonal (right panel) winds. Contours are spaced at $5 \mathrm{~m} \mathrm{~s}^{-1}$ intervals and the thick black contour is the zero wind line.

although the mean wind is subject to large quasi-periodic oscillations throughout the year. The meridional wind is weak (between $\pm 10 \mathrm{~m} \mathrm{~s}^{-1}$ all year) and less perturbed than the zonal wind, especially during the summer months.

To summarise the data, and for direct comparison with other sites (e.g. Figs. 9 and 11 in Fritts et al., 2010), the individual hourly mean fitted horizontal wind components can be averaged together by hour and month to generate a superposed epoch of the monthly mean day. Figure 6 shows the monthly mean zonal and meridional winds recorded between 18 February 2010 and 28 February 2011 as a function of hour of day and month of year. Strong semidiurnal periodicities are clearly seen in both horizontal components of the data throughout the year and are especially strong around early winter, but much weaker in summer. The monthly mean amplitude and phase of the three tidal periodicities $(24,12$ and $8 \mathrm{~h}$ ) together with a background wind were then calculated by fitting to both the zonal and meridional components of these data independently and are presented in Fig. 7. The monthly mean 24-h component (Fig. 7a) is weak throughout the year with typical amplitudes below $8 \mathrm{~m} \mathrm{~s}^{-1}$. The meridional component has a maximum in May and the zonal component is significantly stronger during November and December than during the rest of the year. The phase (measured by the local time of maximum) of the meridional component is around 00:00 LT in summer and slightly earlier during the winter months. The zonal component has a similar summer time phase but drifts to much earlier times during winter. The 12-h wave (Fig. 7b) maximizes in May with monthly mean amplitudes of around $20 \mathrm{~m} \mathrm{~s}^{-1}$ in both the zonal and meridional components. The amplitudes of the two components track each other closely throughout the year. There is a secondary maximum in amplitude in August at around $15 \mathrm{~m} \mathrm{~s}^{-1}$ and the monthly mean amplitudes drop to the smallest values in the summer months of December to February when the phase of the daily fitted wave is seen to vary most. Outside of these summer months the phase of the zonal component of the wave lags the meridional component by three hours 

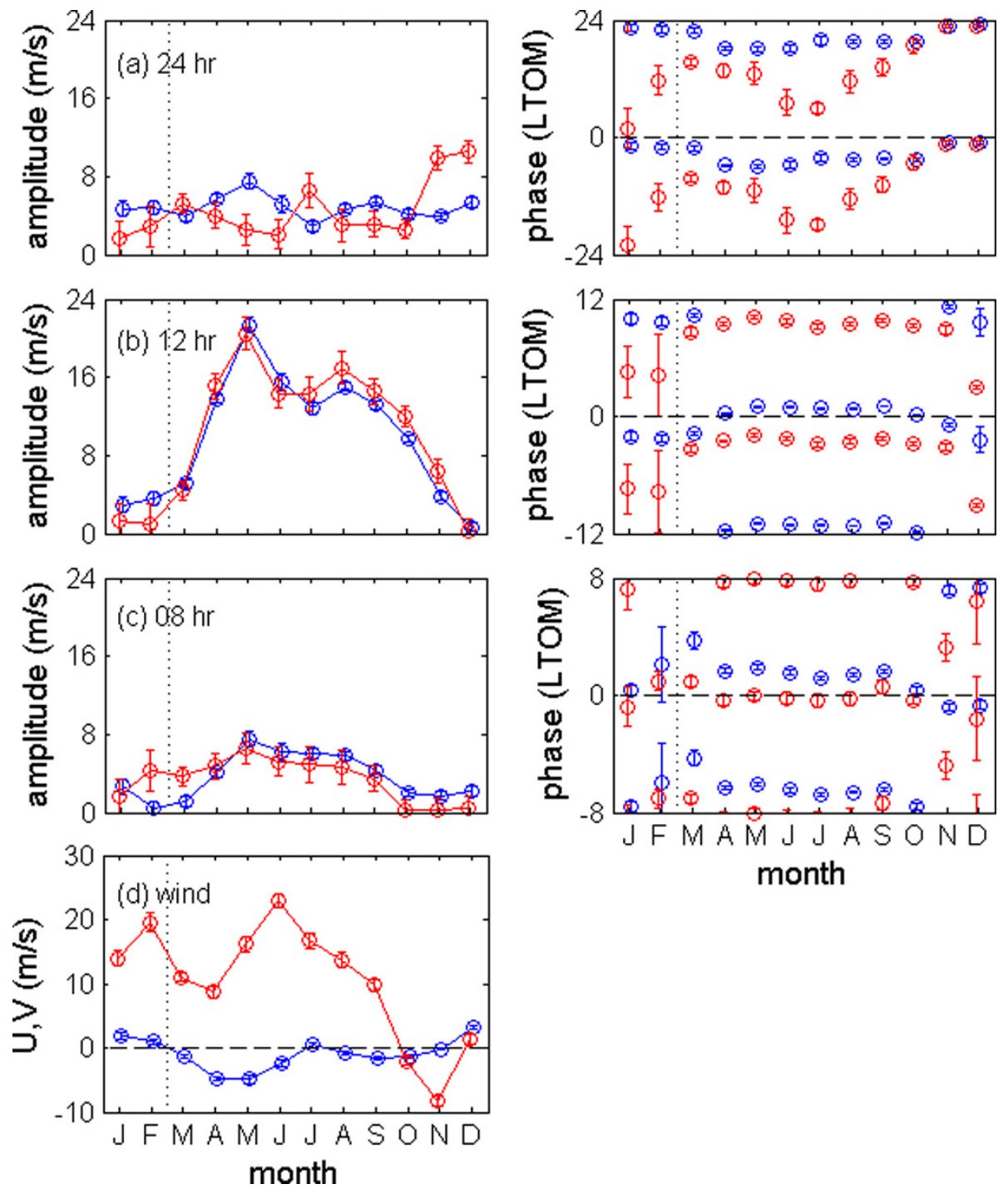

month

Fig. 7. Monthly mean amplitude and phase of the zonal (red; positive eastward) and meridional (blue; positive northward) components of the 24-h (a), 12-h (b), and 8-h (c) waves, and the background wind (d). Wave phases are plotted as the local time of maximum (LTOM) and are repeated over two cycles to show coherence. Error bars represent $95 \%$ confidence intervals on the monthly mean fits.

throughout the year with a slightly later time of maximum around the equinoxes compared to midwinter. During the summer months the time of maximum of both components is much earlier although it is poorly defined in the small fitted mean amplitudes of the superposed epochs. The 8-h wave (Fig. 7c) tracks the seasonal behaviour of the 12-h wave with approximately one third of the fitted amplitude. Both components peak in May, and are small or statistically insignificant during the summer months. The local time of maximum of the wave is slightly later than that of the 12 -h wave and the zonal component precedes the meridional component by around $2 \mathrm{~h}$ when the wave is measureable.

The monthly mean residual wind (after the fitted components are subtracted) is presented in Fig. 7d. The zonal wind is seen to be eastwards all year apart from October and
November when the wind is weakly westwards. The monthly mean zonal wind peaks in June at $22 \mathrm{~m} \mathrm{~s}^{-1}$ with a secondary maximum in February which is only slightly weaker. The meridional component of the wind is small and polewards throughout the year apart from the summer months of December to February when the wind is typically a couple of $\mathrm{m} \mathrm{s}^{-1}$ equatorward. The strongest monthly mean meridional wind occurs in May at $\sim-5 \mathrm{~m} \mathrm{~s}^{-1}$ (poleward).

\section{Discussion}

During the 12 months of observations, the strongest quasiperiodic oscillation seen in these data is the burst of $\sim 48 \mathrm{~h}$ period wave activity in January 2011 which reaches 
amplitudes around $60 \mathrm{~m} \mathrm{~s}^{-1}$ (Fig. 5a). The burst-like nature of the summer-time quasi two-day wave at mid and high latitudes has been extensively reported (e.g. Limpasuvan et al., 2005; Baumgaertner et al., 2008) as has the tendency for the mean period to vary by several hours. This variable periodicity is probably due to the superposition of several different horizontal wavenumber modes (Malinga and Ruohoniemi, 2007). Baumgaertner et al. (2008) discuss the role of baroclinic instabilities (Plumb, 1983) in the in-situ generation of the summer time two day wave, and we note that Fritts et al. (2010) observe a region of high zonal wind shear around $90 \mathrm{~km}$ altitude in their observations during December (2008) and January (2009).

The 12-h wave during the winter months is strong and phase-locked in local time indicative of a single dominant sun-synchronous semidiurnal tide (Figs. 5c and 7b). The wave shows clear phase quadrature with the zonal component leading the meridional component by $3 \mathrm{~h}$ throughout the months of March to November. During the summer months the tide weakens (particularly evident in the vector-averaged monthly means - Fig. 7b) and the phase is no longer locked in local time. Murphy (2002) has demonstrated how this behaviour can result from the constructive and destructive interference between a migrating and non-migrating tide. Previous multi-station ground-based and satellite studies have shown that the semidiurnal tide is composed of a mixture of migrating and non-migrating components at high southern latitudes (Murphy et al., 2006; Baumgaertner et al., 2006; Iimura et al., 2009; Hibbins et al., 2010) away from the pure $S=1$ westwards propagating wave seen at the South Pole (Forbes et al., 1995). Although the single-site observations presented here are incapable of resolving the migrating from the non-migrating components of the semidiurnal tide, the seasonal behaviour of the 12-h wave provides strong observational evidence that the Southern Hemisphere non-migrating components extend further equatorwards than previously demonstrated. Vector comparison of the semidiurnal tide observed in the FIR data with that observed with similar latitude SuperDARN radars at Kerguelen Island, Tasmania and New Zealand to determine the extent of the nonmigrating component(s) of the semidiurnal tide will be the subject of a future paper.

We now compare the results presented here with equivalent data from similar southern and northern latitudes, higher southern latitudes and the HWM-07 empirical horizontal wind model. Although the data represent only one year, and previous studies have revealed significant natural interannual variability in the MLT region (e.g. Fraser et al., 1989; Portnyagin et al., 2006; Baumgaertner et al., 2006; Hibbins et al., 2007a; Sandford et al., 2010) we aim to highlight and interpret some of the observed similarities and differences.

\subsection{Comparison with the SAAMER meteor radar}

Fritts et al. (2010) used a meteor radar located at Rio Grande on Tierra del Fuego $\left(54^{\circ} \mathrm{S}, 68^{\circ} \mathrm{W}\right)$ to study the large scale winds and tides at meteor ablation altitudes during the period May 2008 to September 2009. Although no detailed climatological information on the terdiurnal tide or quasi two-day wave was presented, the data, recorded at a vertical resolution of $3 \mathrm{~km}$, are compared here to the Falkland Islands SuperDARN radar data presented above. The background winds around $90 \mathrm{~km}$ altitude are very similar. The zonal wind is eastwards all year (with maxima in February and July) apart from a brief period around November and December when the winds turn slightly westwards. The meridional wind is weak and equatorwards in summer and mostly polewards during the winter months. The $90 \mathrm{~km}$ diurnal tide in Fritts et al. (2010) is also very similar to that reported here - a weak and variable wave, typically less than $8 \mathrm{~m} \mathrm{~s}^{-1}$ amplitude all year, with a time of maximum around $-06: 00$ to 00:00 LT in the meridional component at the latest in summer.

Qualitatively the semidiurnal tide displays a similar seasonal pattern over Rio Grande as that observed with the Falkland Islands radar. Amplitude maxima are observed in both components in May with a secondary peak in later winter reducing to near insignificant monthly mean amplitudes in summer. However the amplitude of the wintertime wave observed in the SAAMER data is significantly greater than that observed in the data reported here. The reason for this is probably the lack of height finding in the SuperDARN data. The SAAMER radar (with height finding) reveals a wintertime vertical wavelength of about $50 \mathrm{~km}$, i.e. the phase of the wave changes by a complete cycle over $50 \mathrm{~km}$. In the SuperDARN data this phase change with altitude causes partial destructive interference of the wave - the radar sees the Gaussian-weighted vector average over the entire range of meteor ablation altitudes. Assuming that the vertical profile of the meteors observed by the SuperDARN radar can be represented by a Gaussian distribution centred on $90 \mathrm{~km}$ with a full width at half maximum of $12 \mathrm{~km}$ (e.g. Fig. 2 in Fritts et al., 2010), Fig. 8 shows the ratio of the observed amplitude to the "true" amplitude of a wave as a function of its vertical wavelength as seen by the radar. At very small vertical wavelengths $(<10 \mathrm{~km})$ the SuperDARN radar sees no wave amplitude at all as the wave undergoes complete destructive interference within the profile of meteor ablation altitudes. At typical semidiurnal tide wintertime vertical wavelengths around $50 \mathrm{~km}$ (Fritts et al., 2010) the SuperDARN radar sees amplitudes around $80 \%$ of the "true" value of the wave. This is in good agreement with the reduced tidal amplitudes reported here compared to those reported in the SAAMER climatology. 


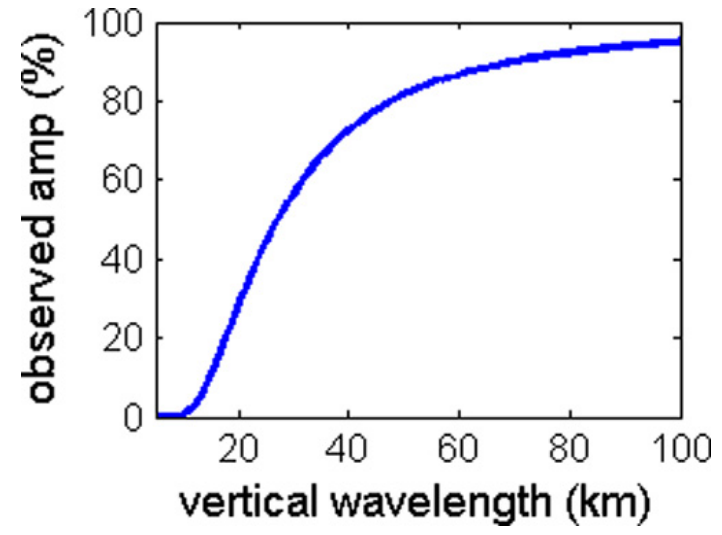

Fig. 8. Ratio of the observed to "true" amplitude of an atmospheric wave observed by the SuperDARN radar plotted as a function of the wave's vertical wavelength.

\subsection{Comparison with high latitude data}

At higher latitude and a similar longitude (see Fig. 1), both MF radar (Hibbins et al., 2005, 2007b) and meteor wind (Sandford et al., 2010) climatologies from Rothera $\left(68^{\circ} \mathrm{S}\right.$, $68^{\circ} \mathrm{W}$ ) on the Antarctic Peninsula can be compared with these results. The mean zonal wind at Rothera around $90 \mathrm{~km}$ altitude is seen to be westwards between mid-October and early January in meteor radar observations (Sandford et al., 2010) and eastwards during the rest of the year peaking at over $15 \mathrm{~m} \mathrm{~s}^{-1}$ in February and August. Thus, the higher latitude site has a remarkably similar qualitative seasonal pattern with a tendency for slightly more westward winds throughout the year. MF radar observations from Rothera (Hibbins et al., 2005) show predominantly eastward winds all year at $90 \mathrm{~km}$ with a wintertime maximum around $15 \mathrm{~m} \mathrm{~s}^{-1}$. The mean meridional winds at higher latitudes are equatorward all year in the MF radar data and similarly in the meteor wind data from Rothera apart from a brief period of polewards flow in April and May at the same time as the FIR meridional winds are at their strongest polewards. Thus the FIR data are qualitatively similar to the Rothera data with a bias of a few $\mathrm{ms}^{-1}$ more polewards throughout the year which, given the small magnitude of the winds, is sufficient to reverse the mean wind direction during winter compared to the higher latitude site. Similarly weak diurnal tides are observed with the MF radar over Rothera at $90 \mathrm{~km}$ (Hibbins et al., 2007b) compared to the data presented here, with maximum amplitudes around $8 \mathrm{~m} \mathrm{~s}^{-1}$ in the summer months. The semidiurnal tide is much weaker over Rothera than the Falkland Islands, but displays a similar seasonality with a maximum in May-June, and the terdiurnal tide is very different at the high latitude site with a weak maximum in summer compared to the early winter maximum seen here.

\subsection{Comparison with equivalent northern latitude data}

The location of FIR is almost exactly geographically conjugate with the near-identical SuperDARN radar at Goose Bay, Canada $\left(53^{\circ} \mathrm{N}, 60^{\circ} \mathrm{W}\right)$. In fact the two sites are within one degree in both longitude and latitude (see Fig. 1) offering an excellent opportunity to compare the behaviour of the mid latitude Northern and Southern Hemisphere upper mesosphere. To this end we have derived climatological mean wind and tide data in exactly the same way as described above from the Goose Bay data spanning September 1993 to August 2009. Amplitudes and phases of the three tidal components in the meridional wind are presented in Fig. 9. The Goose Bay data, as presented, are shifted in time by six months, and the phases are presented as local time of maximum equatorwards to aid the comparison. Included on the plots (dotted lines) are the equivalent data from the HWM-07 horizontal wind empirical model of Drob et al. (2008). These model winds are generated for quiet solar conditions and averaged over $10 \mathrm{~km}$ of altitude from 85 to $95 \mathrm{~km}$ for direct comparison with the observations presented here. Comparison of the FIR data with the model and the climatological mean data from Goose Bay are made here to highlight interhemispheric differences and similarities.

The diurnal tide is similar at both sites (Fig. 9a). The tide has a typical amplitude below $8 \mathrm{~m} \mathrm{~s}^{-1}$ in both hemispheres throughout the year. Outside the winter months, both sites show consistently weaker diurnal tides than the model which shows amplitude peaks around the equinoxes of up to $14 \mathrm{~m} \mathrm{~s}^{-1}$. By contrast, climatologies of the semidiurnal tide in both hemispheres differ markedly (Fig. 9b). In the Northern Hemisphere, the tide is much stronger during the summer months and weaker during the winter months than in the Southern Hemisphere and peaks around the autumn equinox compared to early winter in the Southern Hemisphere. The seasonal variations in the Northern Hemisphere tide are poorly represented by the model. Outside the summer months, the Southern Hemisphere tide is well represented by the model, but during November to March the model consistently over estimates the strength of the semidiurnal tide. Comparison between the non-migrating modes of the semidiurnal tide in the high latitude North and South Hemisphere reveals substantially weaker non-migrating tides in the north (Iimura et al., 2009, 2010). Thus the migrating tide will be more dominant in the north and the constructive/destructive interference between the migrating and nonmigrating tides at high latitudes will be less pronounced than that observed in the south (e.g. Hibbins et al., 2010).

The terdiurnal tide is also stronger in the winter months in the Southern Hemisphere mid-latitude than the Northern Hemisphere. This could also be related to superposition effects due to migrating and non-migrating components of the tide as discussed above. Seasonally the tide behaves similarly in both hemispheres with an early winter (May in the south and November in the north) maximum and smaller 

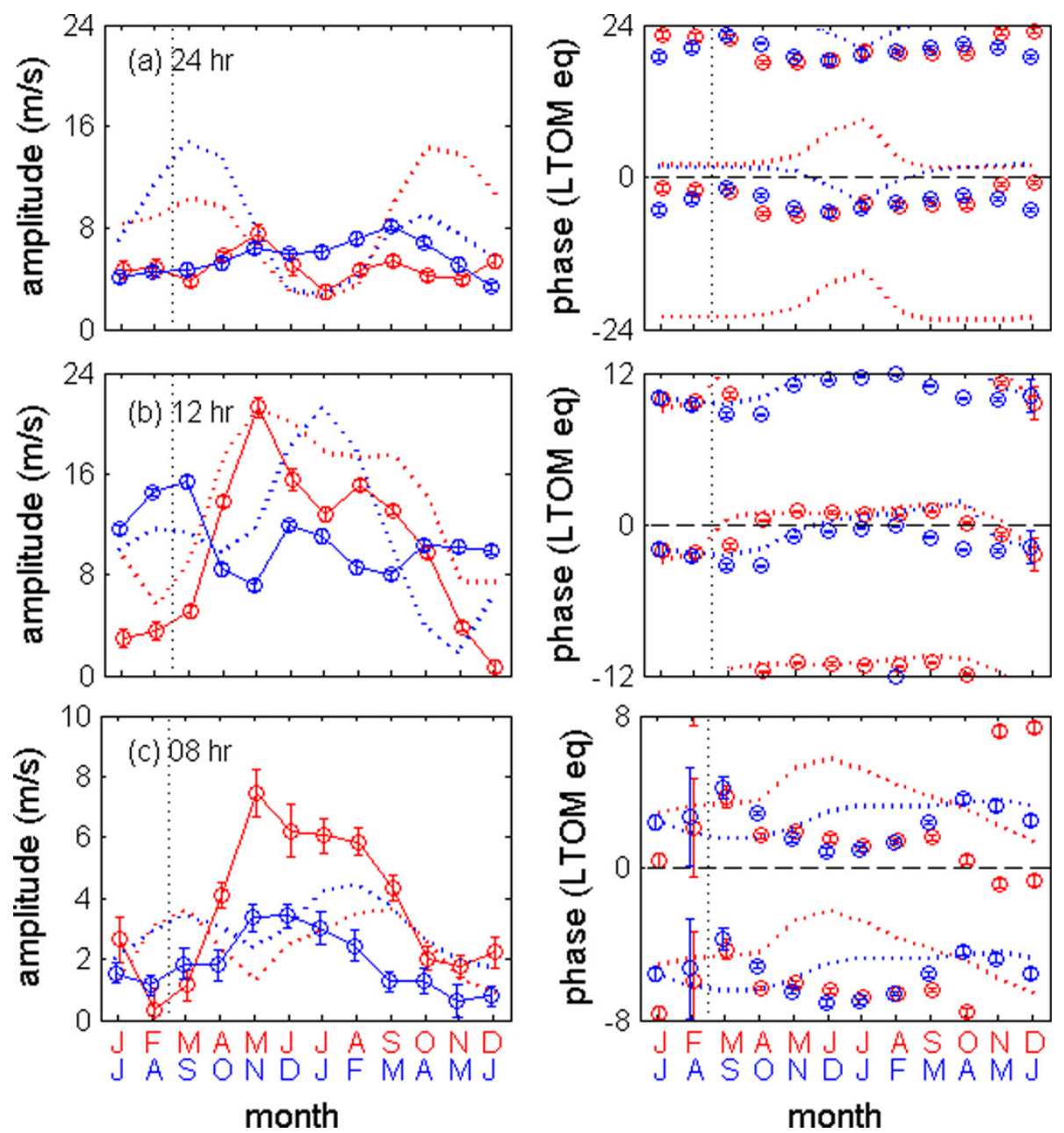

Fig. 9. Monthly mean amplitude and phase of the meridional component of the 24-h (a), 12-h (b), and 8-h (c) waves for the Falkland Islands radar (red) and the Goose Bay radar (blue). Goose Bay data have been shifted by six months and the meridional winds reversed so that all phases are presented as the local time of maximum equatorward winds. Error bars represent $95 \%$ confidence intervals on the monthly mean fits. The dotted lines represent the equivalent data from the HWM-07 model atmosphere averaged between 85 and $95 \mathrm{~km}$ altitude.

amplitudes during summer. Beldon et al. (2006) summarised the mean terdiurnal tide from 16 years of horizontal wind recordings at meteor ablation altitudes taken with a VHF meteor radar at Castle Eaton, UK $\left(53^{\circ} \mathrm{N}, 2^{\circ} \mathrm{W}\right)$. Their data show a similar seasonal behaviour to that presented here with an early winter maximum amplitude around $5 \mathrm{~m} \mathrm{~s}^{-1}$ and a summer minimum. They discuss the possibility that the tide is driven by a non-linear interaction between the diurnal and semidiurnal tides (Glass and Fellous, 1975; Teitelbaum et al., 1989) and it follows here that a larger Southern Hemisphere terdiurnal tide might be expected as the Southern Hemisphere semidiurnal tide is stronger than in the north and the diurnal tides are similar in both hemispheres. The amplitude of the terdiurnal tide is reasonably well represented by the model in the Northern Hemisphere, but the FIR data show much stronger tides than the model, especially during the winter months.
The mean meridional winds (Fig. 10a) are similar in both hemispheres, although slightly more equatorwards in the north than in the south. The model predicts strong $\left(10 \mathrm{~m} \mathrm{~s}^{-1}\right)$ equatorwards flow in the Southern Hemisphere winter which is not observed in the data. The zonal winds (Fig. 10b) are more strongly eastwards in the Southern Hemisphere, as predicted by the model. However, the magnitude of the model winds is over-estimated throughout the year in both hemispheres when compared to the data presented here.

Sandford et al. (2010) compared climatologies of the high latitude Northern and Southern Hemisphere horizontal wind over meteor ablation altitudes measured with two nearidentical Skiymet meteor radar systems located at Rothera $\left(68^{\circ} \mathrm{S}, 68^{\circ} \mathrm{W}\right)$ and Esrange $\left(68^{\circ} \mathrm{N}, 21^{\circ} \mathrm{E}\right)$. In common with the interhemispheric comparisons presented here, they noted a stronger westwards flow in the Southern Hemisphere early summer than that recorded in the north. They observed 

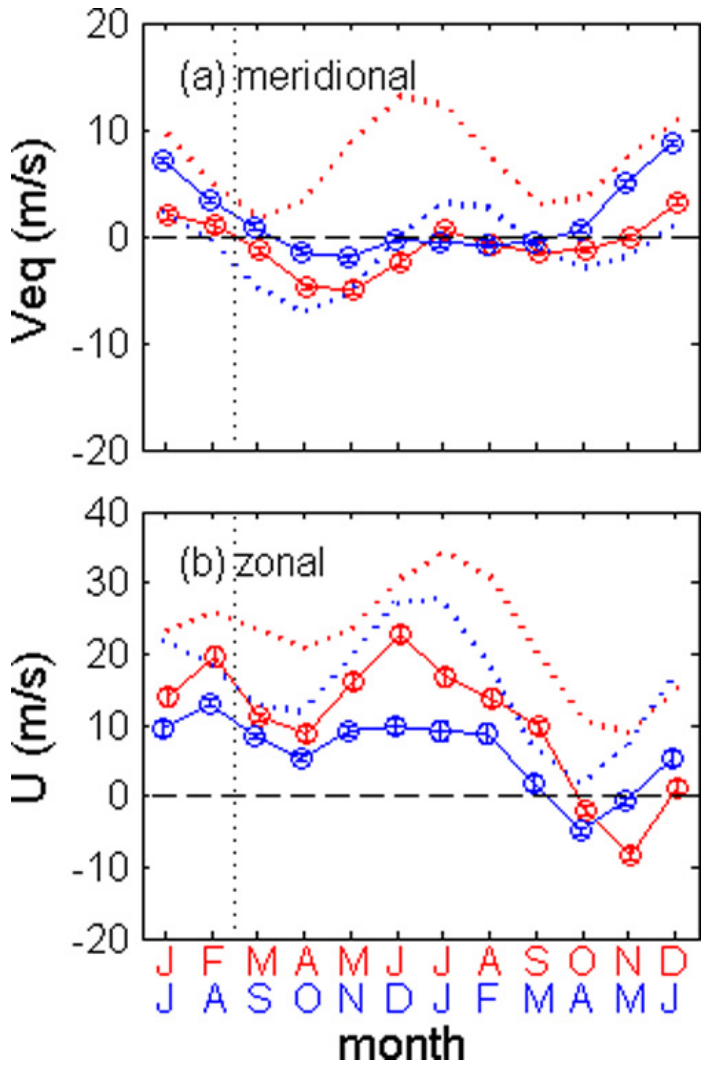

Fig. 10. As Fig. 9 but for the meridional, equatorward positive winds (a) and the zonal, eastward positive winds (b).

similar winter-time zonal winds at both high latitude sites with a tendency for slightly stronger Southern Hemisphere winds during late winter. Here we observe Southern Hemisphere zonal winds that are consistently stronger by a factor of around 2 during January to September compared to the seasonal equivalent months in the Northern Hemisphere (July to February). This interhemispheric difference is also observed in the wintertime stratospheric mid-latitude eastwards zonal winds which tend to be stronger and longer lasting in the Southern Hemisphere than in the Northern Hemisphere (e.g. Siskind et al., 2003). At $90 \mathrm{~km}$ altitude Sandford et al. (2010) report equatorwards flow throughout the year apart from a period around April at Rothera and February at Esrange. By contrast, these lower latitude observations reveal polewards flow during the winter months (slightly stronger in the Southern Hemisphere than in the north), and equatorwards flow in the summer which is stronger and longer lasting in the north than in the south.

\section{Conclusions}

We have derived time series and monthly mean climatologies of the high-frequency periodic oscillations and background mean winds recorded between February 2010 and
February 2011 from meteor drift velocities observed with a SuperDARN radar located at Goose Green in the Falkland Islands $\left(51^{\circ} 50^{\prime} \mathrm{S}, 58^{\circ} 59^{\prime} \mathrm{W}\right)$. The strongest oscillations are observed in a burst of quasi two-day wave activity around the end of January which reached amplitudes approaching $60 \mathrm{~m} \mathrm{~s}^{-1}$ from a wave with a mean period of around $46.5 \mathrm{~h}$. Very strong semidiurnal tidal oscillations were also observed maximising in May 2010 with daily amplitudes greater than $30 \mathrm{~m} \mathrm{~s}^{-1}$. Throughout the winter the phase of the semidiurnal tide is found to be locked in local time indicative of a dominant migrating $S=2$ wave. This behaviour is seen to break down around early November around the same time as the mean zonal wind direction switches from eastwards to westwards. A terdiurnal tide is also observed with similar characteristics to the semidiurnal tide, but with a mean amplitude around one third that of the $12 \mathrm{~h}$ wave.

The data show good agreement with measurements at $90 \mathrm{~km}$ altitude from the relatively nearby SAAMER meteor radar (Fritts et al., 2010) although we demonstrate that the SuperDARN radar can under-estimate the amplitude of waves with small $(<60 \mathrm{~km})$ vertical wavelengths.

The Falkland Islands background winds are seen to be slightly more polewards and more eastwards than those observed with a meteor radar at a higher latitude site at Rothera on the Antarctic Peninsula. The semidiurnal tide is observed to be much stronger than equivalent MF radar observations from Rothera although the seasonal pattern of the tidal amplitudes is very similar. Comparison with the HWM-07 empirical model shows weaker diurnal tides and much stronger terdiurnal tides than those predicted by the model. In addition the mean winds are more poleward and less strongly eastward than the model winds at this latitude.

Comparison with data recorded from a similar SuperDARN radar in the Northern Hemisphere situated at a nearly identical longitude and equivalent latitude reveal several key interhemispheric differences:

- the winter semidiurnal tide is much stronger in the south, whereas in summer it is stronger in the north,

- the winter terdiurnal tide is approximately twice as strong in the Southern Hemisphere,

- the eastwards zonal mean wind in the Southern Hemisphere winter is approximately twice as strong as that observed at the same latitude in the north,

- the equatorwards meridional flow in summer is much stronger in the Northern Hemisphere than in the south and persists for six months compared to three in the south.

Data from the first year of operations enables us to conclude that the Falkland Islands SuperDARN radar will generate an important data set on the dynamics of the mid latitude Southern Hemisphere upper mesosphere. The data have been shown to be of high quality and can be used to generate 
meaningful climatologies of tidal and planetary wave activity providing an exacting test against which global models of atmospheric dynamics can be compared.

Acknowledgements. Funding for the Falkland Islands radar was provided by the UK Natural Environment Research Council (grant numbers NE/G018707/1 and NE/G019665/1). We would like to thank the many people in the Falkland Islands and the UK who have contributed to the FIR project in many different ways, including Nick Alford, Paul Breen, Neil Cobbett, Steve Lucas, Diane McGill, Kath Nicholson, Pauline Sackett, and Jill Thompson (BAS), Mick Parsons, Chris Thomas, and Julian Thornhill (U. Leicester), Mario and Sharon Zuvic-Bulic (KTV Ltd), Andrew Newman, Anthony Payne and Fiona Wallace-Nannig (Falkland Islands Government), Owen Summers (Falklands Landholdings), and Trudy Lee (Goose Green). We acknowledge the support of Goose Bay radar operations and the SuperDARN Upper Atmosphere Facility under US National Science Foundation Grant No. AGS-0849031 and Grant No. AGS-0946900.

Topical Editor C. Jacobi thanks C. Meek for his help in evaluating this paper.

\section{References}

Andrioli, V. F., Clemesha, B. R., Batista, P. P., and Schuch, N. J.: Atmospheric tides and mean winds in the meteor region over Santa Maria (29.7 degrees S; 53.8 degrees W), J. Atmos. SolarTerr. Phys., 71, 1864-1876, doi:10.1016/j.jastp.2009.07.005, 2009.

Baumgaertner, A. J. G., McDonald, A. J., Fraser, G. J., and Plank, G. E.: Long-term observations of mean winds and tides in the upper mesosphere and lower thermosphere above Scott Base, Antarctica, J. Atmos. Solar-Terr. Phys., 67, 1480-1496, doi:10.1016/j.jastp.2005.07.018, 2005.

Baumgaertner, A. J. G., Jarvis, M. J., McDonald, A. J., and Fraser, G. J.: Observations of the wavenumber 1 and 2 components of the semi-diurnal tide over Antarctica, J. Atmos. Solar-Terr. Phys., 68, 1195-1214, doi:10.1016/j.jastp.2006.03.001, 2006.

Baumgaertner, A. J. G., McDonald, A. J., Hibbins, R. E., Fritts, D. C., Murphy, D. J., and Vincent, R. A.: Short-period planetary waves in the Antarctic middle atmosphere, J. Atmos. Solar-Terr. Phys., 70, 1336-1350, 2008.

Beldon, C. L., Muller, H. G., and Mitchell, N. J.: The 8-hour tide in the mesosphere and lower thermosphere over the UK, 19882004, J. Atmos. Solar-Terr. Phys., 68, 655-668, 2006.

Bristow, W., Yee, J.-H., Zhu, X., and Greenwald, R.: Simultaneous observations of the July 1996 2-day wave event using the Super Dual Auroral Radar Network and the High Resolution Doppler Imager, J. Geophys. Res., 104, 12715-12721, 1999.

Brown, W. O. J., Fraser, G. J., Fukao, S., and Yamamoto, M.: Spaced antenna and interferometric velocity measurements with MF and VHF radars, Radio Sci., 30, 1281-1292, 1995.

Buriti, R. A., Hocking, W. K., Batista, P. P., Medeiros, A. F., and Clemesha, B. R.: Observations of equatorial mesospheric winds over Cariri $\left(7.4^{\circ} \mathrm{S}\right)$ by a meteor radar and comparison with existing models, Ann. Geophys., 26, 485-497, doi:10.5194/angeo26-485-2008, 2008.

Chisham, G., Lester, M., Milan, S. E., Freeman, M. P., Bristow, W. A., Grocott, A., McWilliams, K. A., Ruohoniemi, J. M.,
Yeoman, T. K., Dyson, P. L., Greenwald, R. A., Kikuchi, T., Pinnock, M., Rash, J. P. S., Sato, N., Sofko, G. J., Villain, J.P., and Walker, A. D. M.: A decade of the Super Dual Auroral Radar Network (SuperDARN): scientific achievements, new techniques and future directions, Surv. Geophys., 28, 33-109, doi:10.1007/s10712-007-9017-8, 2007.

Chshyolkova, T., Manson, A. H., Meek, C. E., Avery, S. K., Thorsen, D., MacDougall, J. W., Hocking, W., Murayama, Y., and Igarashi, K.: Planetary wave coupling in the middle atmosphere $(20-90 \mathrm{~km})$ : A CUJO study involving TOMS, MetO and MF radar data, Ann. Geophys., 23, 1103-1121, doi:10.5194/angeo-23-1103-2005, 2005.

Drob, D. P., Emmert, J. T., Crowley, G., Picone, J. M., Shepherd, G. G., Skinner, W., Hays, P., Niciejewski, R. J., Larsen, M., She, C. Y., Meriwether, J. W., Hernandez, G., Jarvis, M. J., Sipler, D. P., Tepley, C. A., O’Brien, M. S., Bowman, J. R., Wu, Q., Murayama, Y., Kawamura, S., Reid, I. M., and Vincent, R. A.: An empirical model of the Earth's horizontal wind fields: HWM07, J. Geophys. Res., 113, A12304, doi:10.1029/2008JA013668, 2008.

Forbes, J. M., Makarov, N., and Portnyagin, Yu. I.: First results from the meteor radar at South Pole: A large 12-hour oscillation with zonal wavenumber one, Geophys. Res. Lett., 22, 32473250, doi:10.1029/95GL03370, 1995.

Fraser, G. J., Vincent, R. A., Manson, A. H., Meek, C. E., and Clark, R. R.: Inter-annual variability of tides in the mesosphere and lower thermosphere, J. Atmos. Terr. Phys., 51, 555-567, 1989.

Fritts, D. C. and Alexander, M. J.: Gravity wave dynamics and effects in the middle atmosphere, Rev. Geophys., 41, 1003, doi:10.1029/2001RG000106, 2003.

Fritts, D. C., Vadas, S. L., Wan, K., and Werne, J. A.: Mean and variable forcing of the middle atmosphere by gravity waves, J. Atmos. Solar-Terr. Phys., 68, 247-265, 2006.

Fritts, D. C., Janches, D., Iimura, H., Hocking, W. K., Mitchell, N. J., Stockwell, R. G., Fuller, B., Vandepeer, B., Hormaechea, J., Brunini, C., and Levato, H.: Southern Argentina Agile Meteor Radar: System design and initial measurements of large-scale winds and tides, J. Geophys. Res., 115, D18112, doi:10.1029/2010JD013850, 2010.

Glass, M. and Fellous, J. L.: Eight-hourly (ter-diurnal) component of atmospheric tides, Space Res., 15, 191-197, 1975.

Greenwald, R. A., Baker, K. B., Hutchines, R. A., and Hanuise, C.: An HF phased-array radar for studying small-scale structure in the high latitude ionosphere, Radio Sci., 20, 63-79, doi:10.1029/RS020i001p00063, 1985.

Greenwald, R. A., Baker, K. B., Dudeney, J. R., Pinnock, M., Jones, T. B., Thomas, E. C., Villain, J. P., Cerisier, J. C., Senior, C., Hanuise, C., Hunsucker, R. D., Sofko, G., Koehler, J., Nielsen, E., Pellinen, R., Walker, A. D. M., Sato, N., and Yamagishi, H.: DARN/SuperDARN: a global view of the dynamics of high latitude convection, Space Sci. Rev., 71, 761-796, doi:10.1007/BF00751350, 1995.

Guo, L. and Lehmacher, G.: First meteor radar observations of tidal oscillations over Jicamarca $\left(11.95^{\circ} \mathrm{S}, 76.87^{\circ} \mathrm{W}\right)$, Ann. Geophys., 27, 2575-2583, doi:10.5194/angeo-27-2575-2009, 2009.

Hall, G. E., MacDougall, J. W., Moorcroft, D. R., St.-Maurice, J.P., Manson, A. H., and Meek, C. E.: Super Dual Auroral Radar Network observations of meteor echoes, J. Geophys. Res., 102, 14603-14614, doi:10.1029/97JA00517, 1997. 
Hibbins, R. E., Shanklin, J. D., Espy, P. J., Jarvis, M. J., Riggin, D. M., Fritts, D. C., and Lübken, F.-J.: Seasonal variations in the horizontal wind structure from $0-100 \mathrm{~km}$ above Rothera station, Antarctica $\left(67^{\circ} \mathrm{S}, 68^{\circ} \mathrm{W}\right)$, Atmos. Chem. Phys., 5, 2973-2980, doi:10.5194/acp-5-2973-2005, 2005.

Hibbins, R. E., Espy, P. J., and Jarvis, M. J.: Mean winds and tides in the mesosphere and lower thermosphere above Halley, Antarctica, J. Atmos. Solar-Terr. Phys., 68, 436-444, doi:10.1016/j.jastp.2005.02.030, 2006.

Hibbins, R. E., Espy, P. J., and Jarvis, M. J.: Quasi-biennial modulation of the semidiurnal tide in the upper mesosphere above Halley, Antarctica, Geophys. Res. Lett., 34, L21804, doi:10.1029/2007GL031282, 2007a.

Hibbins, R. E., Espy, P. J., Jarvis, M. J., Riggin, D. M., and Fritts, D. C.: A climatology of tides and gravity wave variance in the MLT above Rothera, Antarctica obtained by MF radar, J. Atmos. Solar-Terr. Phys., 69, 578-588, 2007 b.

Hibbins, R. E., Marsh, O. J., McDonald, A. J., and Jarvis, M. J.: A new perspective on the longitudinal variability of the semidiurnal tide, Geophys. Res. Lett., 37, L14804, doi:10.1029/2010GL044015, 2010.

Hoffmann, P., Becker, E., Singer, W., and Placke, M.: Seasonal variation of mesospheric waves at northern middle and high latitudes, J. Atmos. Solar-Terr. Phys., 72, 1068-1079, doi:10.1016/j.jastp.2010.07.002, 2010.

Hussey, G. C., Meek, C. E., Andre, D., Manson, A. H., Sofko, G. J., and Hall, C. M.: A comparison of Northern Hemisphere winds using Super-DARN meteor trail and MF radar wind measurements, J. Geophys. Res., 105, 18053-18066, doi:10.1029/2000JD900272, 2000.

Igarashi, K., Namboothiri, S. P., and Kishore, P.: Tidal structure and variability in the mesosphere and lower thermosphere over Yamagawa and Wakkanai, J. Atmos. Solar-Terr. Phys., 64, 10371053, 2002.

Iimura, H., Palo, S. E., Wu, Q., Killeen, T. L., Solomon, S. C., and Skinner, W. R.: Structure of the nonmigrating semidiurnal tide above Antarctica observed from the TIMED Doppler Interferometer, J. Geophys. Res., 114, D11102, doi:10.1029/2008JD010608, 2009.

Iimura, H., Fritts, D. C., Wu, Q., Skinner, W. R., and Palo, S. E.: Nonmigrating semidiurnal tide over the Arctic determined from TIMED Doppler Interferometer wind observations, J. Geophys. Res., 115, D06109, doi:10.1029/2009JD012733, 2010.

Jacobi, Ch., Froehlilch, K., Viehweg, C., Stober, G., and Kuerschner, D.: Midlatitude mesosphere/lower thermosphere meridional winds and temperatures measured with meteor radar, Adv. Space Res., 39, 1278-1283, doi:10.1016/j.asr.2007.01.003, 2007

Jacobi, Ch., Arras, C., Kurschner, D., Singer, W., Hoffmann, P., and Keuer, D.: Comparison of mesopause region meteor radar winds, medium frequency radar winds and low frequency drifts over Germany, Adv. Space Res., 43, 247-252, doi:10.1016/j.asr.2008.05.009, 2009.

Kovalam, S. and Vincent, R. A.: Intra-diurnal wind variations in the mid-latitude and high-latitude mesosphere and lower thermosphere, J. Geophys. Res., 108, 4135, doi:10.1029/2002JD002500, 2003.

Lima, L. M., Batista, P. P., Clemesha, B. R., and Takahashi, H.: The 6.5-day oscillations observed in meteor winds over $\mathrm{Ca}$ - choeira Paulista (22.7 degrees S), Adv. Space Res., 36, 2212 2217, doi:10.1016/j.asr.2005.06.005, 2005.

Lima, L. M., Batista, P. P., Clemesha, B. R., and Takahashi, H.: 16-day wave observed in the meteor winds at low latitudes in the southern hemisphere, Adv. Space Res., 38, 2615-2620, doi:10.1016/j.asr.2006.03.033, 2006.

Limpasuvan, V., Wu, D. L., Schwartz, M. J., Waters, J. W., Wu, Q., and Killeen, T. L.: The two-day wave in EOS MLS temperature and wind measurements during 2004-2005 winter, Geophys. Res. Lett., 32, L17809, doi:10.1029/2005GL023396, 2005.

Luo, Y., Manson, A. H., Meek, C. E., Igarashi, K., and Jacobi, Ch.: Extra long period (20-40 day) oscillations in the mesospheric and lower thermospheric winds: observations in Canada, Europe and Japan, and considerations of possible solar influences, J. Atmos. Solar-Terr. Phys., 63, 835-852, 2001.

Luo, Y., Manson, A. H., Meek, C. E., Thayaparan, T., MacDougall, J., and Hocking, W. K.: The 16-day wave in the mesosphere and lower thermosphere: simultaneous observations at Saskatoon (52 degrees N, 107 degrees $\mathrm{W}$ ) and London (43 degrees N, 81 degrees W), Canada, J. Atmos. Solar-Terr. Phys., 64, 1287-1307, 2002.

Lysenko, I. A., Portnyagin, Yu. I., Fakhrutdinova, A. N., Ishmuratov, R. A., Manson, A. H., and Meek, C. E.: Wind regime at 80-110 km at midlatitudes of the northern-hemisphere, J. Atmos. Terr. Phys., 56, 31-42, 1994.

Malinga, S. B. and Poole, L. M. G.: The 16-day variation in the mean flow at Grahamstown $\left(33.3^{\circ} \mathrm{S}, 26.5^{\circ} \mathrm{E}\right)$, Ann. Geophys., 20, 2027-2031, doi:10.5194/angeo-20-2027-2002, 2002.

Malinga, S. B. and Ruohoniemi, J. M.: The quasi-two-day wave studied using the Northern Hemisphere SuperDARN HF radars, Ann. Geophys., 25, 1767-1778, doi:10.5194/angeo-25-17672007, 2007.

Manson, A. H., Meek, C. E., Luo, Y., Hocking, W. K., MacDougall, J., Riggin, D. M., Fritts, D. C., and Vincent, R. A.: Modulation of gravity waves by planetary waves ( 2 and $16 \mathrm{~d}$ ): observations with the North American-Pacific MLT-MFR radar network, J. Atmos. Solar-Terr. Phys., 65, 85-104, 2003.

Manson, A. H., Meek, C. E., Chshyolkova, T., Avery, S. K., Thorsen, D., MacDougall, J. W., Hocking, W., Murayama, Y., Igarashi, K., Namboothiri, S. P., and Kishore, P.: Longitudinal and latitudinal variations in dynamic characteristics of the MLT (70-95 km): a study involving the CUJO network, Ann. Geophys., 22, 347-365, doi:10.5194/angeo-22-347-2004, 2004.

Manson, A. H., Meek, C. E., Chshyolkova, T., Avery, S. K., Thorsen, D., MacDougall, J. W., Hocking, W., Murayama, Y., and Igarashi, K.: Wave activity (planetary, tidal) throughout the middle atmosphere (20-100 km) over the CUJO network: Satellite (TOMS) and Medium Frequency (MF) radar observations, Ann. Geophys., 23, 305-323, doi:10.5194/angeo-23-305-2005, 2005.

Merzlyakov, E. G., Portnyagin, Yu. I., Jacobi, C., Mitchell, N. J., Muller, H. G., Manson, A. H., Fachrutdinova, A. N., Singer, W., and Hoffmann, P.: On the longitudinal structure of the transient day-to-day variation of the semidiurnal tide in the mid-latitude lower thermosphere - I. Winter season, Ann. Geophys., 19, 545562, doi:10.5194/angeo-19-545-2001, 2001.

Merzlyakov, E. G., Murphy, D. J., Vincent, R. A., and Portnyagin, Yu. I.: Long-term tendencies in the MLT prevailing winds and tides over Antarctica as observed by radars at Molodezh- 
naya, Mawson and Davis, J. Atmos. Solar-Terr. Phys., 71, 21-32, doi:10.1016/j.jastp.2008.09.024, 2009.

Middleton, H. R., Mitchell, N. J., and Muller, H. G.: Mean winds of the mesosphere and lower thermosphere at $52^{\circ} \mathrm{N}$ in the period 1988-2000, Ann. Geophys., 20, 81-91, doi:10.5194/angeo-2081-2002, 2002.

Mitchell, N. J., Middleton, H. R., Beard, A. G., Williams, P. J. S., and Muller, H. G.: The 16-day planetary wave in the mesosphere and lower thermosphere, Ann. Geophys., 17, 1447-1456, doi:10.1007/s00585-999-1447-9, 1999.

Murphy, D. J.: Variations in the phase of the semidiurnal tide over Davis, Antarctica, J. Atmos. Sol. Terr. Phys., 64, 1069-1081, doi:10.1016/S1364-6826(02)00058-5, 2002.

Murphy, D. J., Forbes, J. M., Walterscheid, R. L., Hagan, M. E., Avery, S. K., Aso, T., Fraser, G. J., Fritts, D. C., Jarvis, M. J., McDonald, A. J., Riggin, D. M., Tsutsumi, M., and Vincent R. A.: A climatology of tides in the Antarctic mesosphere and lower thermosphere, J. Geophys. Res., 111, D23104, doi:10.1029/2005JD006803, 2006.

Offermann, D., Gusev, O., Donner, M., Forbes, J. M., Hagan, M., Mlynczak, M. G., Oberheide, J., Preusse, P., Schmidt, H., Russell, J. M.: Relative intensities of middle atmosphere waves, J. Geophys. Res., 114, D06110, doi:10.1029/2008JD010662, 2009.

Pancheva, D. V.: Evidence for nonlinear coupling of planetary waves and tides in the lower thermosphere over Bulgaria, J. Atmos. Solar-Terr. Phys., 62, 115-132, 2000.

Pancheva, D. V.: Quasi-2-day wave and tidal variability observed over Ascension Island during January/February 2003, J. Atmos. Solar-Terr. Phys., 68, 390-407, doi:10.1016/j.jastp.2005.02.028, 2006.

Plumb, R. A.: Baroclinic instability of the summer mesosphere: a mechanism for the quasi-two-day wave?, J. Atmos. Sci., 40, 262-270, 1983.
Portnyagin, Y. I., Forbes, J. M., Makarov, N. A., Merzlyakov, E. G., and Palo, S.: The summertime 12-h wind oscillation with zonal wavenumber $s=1$ in the lower thermosphere over the South Pole, Ann. Geophys., 16, 828-837, doi:10.1007/s00585998-0828-9, 1998.

Portnyagin, Yu. I., Merzlyakov, E. G., Solovjova, T. V., Jacobi, Ch., Kuerschner, D., Manson, A. H., and Meek, C. E.: Longterm trends and year-to-year variability of mid-latitude mesosphere/lower thermosphere winds, J. Atmos. Solar-Terr. Phys., 68, 1890-1901, 2006.

Sandford, D. J., Beldon, C. L., Hibbins, R. E., and Mitchell, N. J.: Dynamics of the Antarctic and Arctic mesosphere and lower thermosphere - Part 1: Mean winds, Atmos. Chem. Phys., 10, 10273-10289, doi:10.5194/acp-10-10273-2010, 2010.

Siskind, D. E., Eckermann, S. D., McCormack, J. P., Alexander, M. J., and Bacmeister, J. T.: Hemispheric differences in the temperature of the summertime stratosphere and mesosphere, J. Geophys. Res., 108, 4051, doi:10.1029/2002JD002095, 2003.

Teitelbaum, H., Vial, F., Manson, A.H., Giraldez, R., and Massebeuf, M.: Non-linear interaction between the diurnal and semidiurnal tides - terdiurnal and diurnal secondary waves, J. Atmos. Terr. Phys., 51, 627-634, 1989.

Younger, P. T., Astin, I., Sandford, D. J., and Mitchell, N. J.: The sporadic radiant and distribution of meteors in the atmosphere as observed by VHF radar at Arctic, Antarctic and equatorial latitudes, Ann. Geophys., 27, 2831-2841, doi:10.5194/angeo-272831-2009, 2009.

Yukimatu, A. S. and Tsutsumi, M.: A new SuperDARN meteor wind measurement: Raw time series analysis method and its application to mesopause region dynamics, Geophys. Res. Lett., 29, 1981, doi:10.1029/2002GL015210, 2002. 